Introduction to the topic

HNO 2019 67 (Suppl 2):S43-S45

https://doi.org/10.1007/s00106-019-0624-8

(c) Springer Medizin Verlag GmbH, ein Teil von Springer Nature 2019

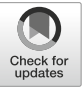

\author{
B. Mazurek' $\cdot$ M. Knipper ${ }^{2} \cdot$ E. Biesinger $^{3} \cdot$ H. Schulze ${ }^{4}$ \\ ${ }^{1}$ Tinnitus Center, Charité-Universitätsmedizin Berlin, Berlin, Germany \\ ${ }^{2}$ Department of Otolaryngology, Head \& Neck Surgery, Tübingen Hearing Research Centre (THRC), \\ Molecular Physiology of Hearing, University of Tübingen, Tübingen, Germany \\ ${ }^{3}$ ENT-Clinic Traunstein, Traunstein, Germany \\ ${ }^{4}$ Experimental Otolaryngology, Department of Otorhinolaryngology - Head and Neck Surgery, University \\ of Erlangen, Erlangen, Germany
}

\title{
Special issues for the 55th Inner Ear Biology Workshop 06.-08.09.2018 in Berlin
}

\section{Basic research and clinical aspects- translational aspects of hearing research}

The ability to hear and listen is of great importance for communication and special as well as social orientation and is therefore a crucial determinant for human quality of life and social integration $[1,2]$.

\section{) There are 466 million people suffering from hearing impairment worldwide}

Disorders of the auditory as well as associated systems, such as hearing impairment or tinnitus, are common and rapidly increasing. According to recent estimates by the World Health Organization (WHO), 466 million people worldwide suffer from hearing impairment $-5 \%$ of the world's population [3]. This figure includes 34 million children with hearing disorders.

European studies estimate the tinnitus prevalence as ranging from 12 to $30 \%$ in the general population [4]. About $5 \%$ of people with tinnitus experience mild to moderate tinnitus burden, half of whom experience tinnitus as severely debilitating $[5,6]$. As a result, tinnitus is increasingly becoming a global health problem

The German version of this article can be found under https://doi.org/10.1007/s00106019-0621-y.
$[7,8]$ that severely limits the quality of life of millions of people. By 2050, an estimated 900 million people will be affected by hearing loss. The Global Burden of Disease report, published by the WHO, identifies hearing loss as the 15th most important factor and places it second in terms of reducing quality-adjusted life years [9].

Common causes of hearing loss include genetic factors, infectious diseases, chronic ear infections, side effects of certain medications, aging, and noise exposure [1]. As a result, 1.1 million young people between the ages of 12 and 35 suffer from hearing loss caused by self-imposed noise exposure [3].

The cost of untreated hearing loss amounts to US $\$ 750$ billion annually [3]. Annual treatment cost of tinnitus alone, for example, amounts to US $\$ 19$ billion in the United States and 7 billion Euros in the Netherlands [10].

Therefore, it is politically essential to advocate for hearing prevention. More than half of hearing disorders worldwide are avoidable by prevention and treatment. Special screening programs for newborns are of great relevance for minimizing hearing loss in childhood. Common means of hearing protection-such as reducing noise exposure or avoiding inner ear microphones-can also help to prevent hearing problems. In addition, a large proportion of hearing disorders is already successfully treated with hearing aids or cochlear implants (CIs; [2]). However, the rate of hearing-impaired individuals who take up hearing aids is less than $25 \%$ in the United States [11] and only $20 \%$ in Germany [12].

The crucial importance of early intervention is further emphasized by the fact that hearing loss has been identified as one of nine modifiable risk factors that may impact upon the development of late-life dementia $[13,14]$. Notwithstanding, the extent to which hearing aids may ameliorate this risk is yet to be investigated in well-controlled longitudinal studies.

Studies of uni- or bilateral cochlear implantation for deaf people provide indirect evidence that prevention and treatment of hearing disorders may have positive effects on cognitive performance, quality of life, and emotional well-being [15-21].

The risk of developing a hearing disorder is alarmingly high and the issue requires our utmost attention. Interventions for prevention and treatment of hearing impairment are cost effective and, importantly, are associated with an immensely positive impact on those concerned.

Reflecting these issues, the 55th Inner Ear Biology Workshop (IEB) took place 
in Berlin from 6 to 8 September 2018: researchers and clinicians from 35 countries attended the IEB to exchange knowledge and expertise.

\section{》) The risk of developing a hearing disorder is alarmingly high}

This year's IEB focused on translational research of the inner ear and auditory system with a special accentuation on the translation of basic research findings into newly developed and directly applicable diagnostic and treatment tools. The great number of genes contributing to auditory function reflect the particular complexity of the auditory system [22]. In particular, advances in molecular biology have led to improved detection rates of hearing loss and therefore options of earlier intervention [2].

In humans, more than 150 non-syndromic gene loci (DFNA, DFNB and DFNX) and 400 genetic syndromes involving hearing loss have been identified. In addition, research has identified more than 100 non-syndromic genes in mice and humans that are associated with hearing loss. Naturally, the vast complexity of possible genetic links in the hearing system is by no means exhaustively understood [23, 24]. Similarly, most genes that cause syndromal hearing loss are still unknown [25]. Genetic research collaborations such as the International Mouse Phenotyping Consortium (IMPC) work tirelessly to discover new candidate genes for hearing loss involving large cohorts of mouse knockout strains [22].

Recent years have also brought advances in the discovery and description of inner ear-specific proteins, such as Prestin, Otoferlin, and Pendrin [26]. Furthermore, ENT diagnostics have begun to focus more and more on specific dysfunctions such as genetic and acquired auditory neuropathies - especially in differentiation to synaptopathy [27].

These findings are also highly relevant for personalized ENT interventions that aim to use molecular diagnostics (that consider genomic knowledge, biomarkers, behavioral influences, and environmental influences; [28]). Deciphering the human genome has led to a paradigm shift in the field of ENT diagnostics and therapy: genetic information may allow for new insights into the aetiology of hearing disorders and associated symptoms that are also helpful for providing patients with information, thus enabling them to make informed decisions about treatment pathways [29]. Thus, predictions about the course of hearing impairments or associated risk factors may be facilitated [30]. The use of next-generation DNA sequencing also provides new and exciting information about the genetic causes of hearing disorders.

\section{》) Results of stem cell transplantation in the human inner ear are now available}

An ideal therapy for human hearing loss - the replacement or regeneration of inner and outer hair cells - is not yet available. Nevertheless, our knowledge about such a regeneration process on a molecular level is ever increasing [31-35] and initial results from studies investigating stem cell transplantation into the human inner ear are already available [36]. This exceptional new research has shown that autologoustransplanted human bone marrow stem cells can be used for cell-based intracochlear release of growth factors associated with cochlear implantation. Also, in the field of gene therapy, initial trials are promising, for example for an Atoh1 (Hath1) gene therapy in patients with severe hearing loss using a recombinant adenoviral vector [37].

Selected topics of the IEB also included aspects of stem cell research, synaptic tone coding, findings on synaptopathies, circadian patterns of the cochlea and the auditory system, the influence of growth factors on the progression of hearing disorders, models for tinnitus development, and biological and pharmacological treatment options of the auditory system.

In addition to excellent keynote lectures, the IEB featured workshops on brainstem audiometry in animals, diagnostics in CIs, vestibular diagnostics, psychological comorbidities, hearing aid supply, ENT-related cervical spine diagnostics, as well as an afternoon focusing on patient information. The last day was offered in tandem with the 20th Tinnitus Symposium of the Charité.

For these two special issues of the IEB 2018, we would like to invite you to enjoy new findings and interesting developments across basic research and applied clinical domains.

Sincerely yours,

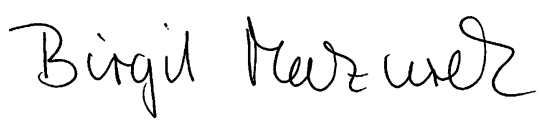

Prof. Dr. Birgit Mazurek

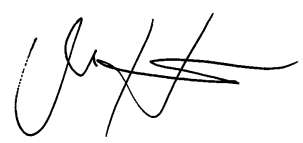

Prof. Dr. Marlies Knipper

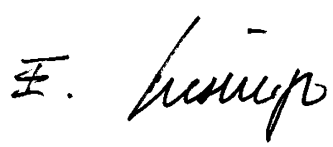

Dr. Eberhard Biesinger

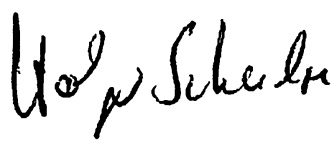

Prof. Dr. Holger Schulze

\section{Corresponding address}

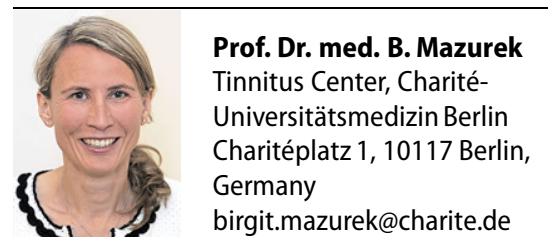

Conflict of interest B. Mazurek, M. Knipper, E. Biesinger, and H. Schulze declare that they have no competing interests.

The supplement containing this article is not sponsored by industry.

\section{References}

1. Streppel M, Walger M, Wedel H, Gaber G (2006) Hörstörungen und Tinnitus. Robert-Koch. Institut, vol 29. ISBN 978-3896061652 
2. Kochhar A, Hildebrand MS, Smith RJH (2007) Clinical aspects of hereditary hearing loss. Genet Med 9(7):393-408

3. World Health Organisation (WHO) www.euro.int. de

4. McCormack A, Edmondson-Jones M, Somerset $S$, Hall D (2016) A systematic review of the reporting of tinnitus prevalence and severity. Hear Res 337:70-79

5. Tyler RS (2000) Tinnitus Handbook TRS. Singular Publishing Group, San Diego

6. Pilgramm M, Rychlik R, Lebisch $H$, Siedentop H, Goebel G, Kirchhoff D (1999) Tinnitus in der Bundesrepublik Deutschland. Eine repräsentative epidemiologische Studie. Hno Aktuell 7(4):261-265

7. Baguley D, McFerran D, Tinnitus HD (2013) Lancet 382(9904):1600-1607

8. Bauer CA, Berry J, Brozoski TJ (2016) Clinical trials supported by the Tinnitus Research Consortium: lessons learned, the Southern Illinois University experience. Hear Res 334:65-71

9. World Health Organization (WHO). The global burden of disease. 2004 update. Geneva: 2004 (cited 20018-12-12) http://www.euro.int.de

10. Maes IH, Cima RF, Vlaeyen JW, Anteunis LJ, Tinnitus JMA (2013) a cost study. Ear Hear 34(4):508-514

11. Lin FR, Niparko JK, Ferrucci L (2011b) Hearing loss prevalence in the United States. Arch Intern Med 171:1851-1852

12. http://www.focus.de/gesundheit/ratgeber/ hoeren/tid-28343/hoergeraete-mit-neuertechnik-endlich-wieder-gut-hoeren_aid_ 871508.html

13. Kim SY, Lim J-S, Kong IG, Choi HG (2018) Hearing impairment and the risk of neurodegenerative dementia: a longitudinal follow — up study using a national sample cohort. Sci Rep 8:1-8

14. Livingston $G$, Sommerlad A, Orgeta V, Costafreda SG, Huntley J, Ames D, Ballard C, Banerjee S, Burns A, Cohen-Mansfield J, Cooper C, Fox N, Gitlin LN, Howard R, Kales HC, Larson EB, RitchieK, Rockwood K, Sampson EL, Samus Q, Schneider LS, Selbvæk G, Teri L, Mukadam N (2017) Dementia prevention, intervention, and care. The. Lancet 390:2673-2734

15. Brueggemann P, Szczepek AJ, Klee K, Graebel S, Mazurek B, Olze H (2017) In Patients Undergoing Cochlear Implantation, Psychological Burden Affects Tinnitus and the Overall Outcome of Auditory Rehabilitation. Front Hum Neurosci $11: 226$

16. Brueggemann P, Szczepek AJ, Rose M, McKenna L, Olze H, Mazurek B (2016) Impact of Multiple Factors on the Degree of Tinnitus Distress. Front Hum Neurosci 10:341

17. Claes AJ, Van de Heyning P, Gilles A, Van Rompaey V, Mertens G (2018) Cognitive outcomes after cochlear implantation in older adults: A systematic review. Cochlear Implants Int 19:239-254

18. Knopke S, Szczepek AJ, Haeussler SM, Graebel S, Olze H (2017) Cochlear Implantation of Bilaterally Deafened Patients with Tinnitus Induces Sustained Decrease of Tinnitus-Related Distress. Front Neurol 8:158

19. Mertens G, Van Rompaey V, Van de Heyning P (2018) Electric-acousticstimulation suppressestinnitus in a subject with high-frequency single-sided deafness. Cochlear Implants Int 19(5):292-296. https://doi.org/10.1080/14670100.2018.1473940

20. Olze H (2015) Cochlear implants and tinnitus. HNO 63:291-297

21. Olze H, Graebel S, Haupt H, Foerster U, Mazurek B (2012) Extra benefit of a second cochlear implant with respect to health-related quality of life and tinnitus. Otology \& neurotology: official publication of the American Otological Society, American Neurotology Society [and] European Academy of. Otol Neurotol 33:1169-1175

22. Bowl MR (2017) A large scale hearing loss screen reveals an extensiveunexplored geneticlandscape for auditory dysfunction. Nat Commun 8(1):886. https://doi.org/10.1038/s41467-017-00595-4

23. Shearer AE, Hildebrand MS, Smith RJH. Hereditary Hearing Loss and Deafness overview (eds. Pagon, RA et al) Genereviews

24. Toriello HV, Reardon W, Gorlin RJ (2004) Hereditary Hearing loss and its syndromes. university Press, Oxford

25. Koffler T, Ushakov K, Avraham KB (2015) Genetics of hearing loss: syndromic. Otolaryngol Clin North Am 48:1041-1061

26. Pangršič T, Reisinger E, Otoferlin MT (2012) a multiC2 domain protein essential for hearing. Trends Neurocience 35(11):671-680

27. Moser T, Starr A (2016) Auditory neuropathyneural and synaptic mechanism. Nat Rev Neurol 12:135-149

28. Rudman JR, Mei C, Bressler SE, Blanton SH, Li X-Z (2018) Precision medicine in hearing loss. J Genet Genomics 45:99-109

29. Friese N, Braun K, Müller M, Tropitzsch A (2015) Personalisierte Medizin in der Otologie. HNO 63:428-433

30. Matsunga $T$ (2009) Value of genetic testing in the otological approach for sensorineural hearing loss. Keio JMed 58(4):216-222

31. Löwenheim H, Waldhus J, Hirt B, Sandke S, Müller M (2008) Regenerative Medizin in der Therapie der Innenohrschwerhörigkeit. HNO 56:288-300

32. Stöver T, Diensthuber M (2011) Molekularbiologie des Gehörs. Laryngo-Rhino-Otol 90:22-34

33. Diensthuber M, Stöver T (2018) Strategien für eine regenerative Therapie der Schwerhörigkeit. HNO 66:179-187

34. Mueller U, Barr-Gillespie PG (2015) New treatment options for hearing loss. Nature 14:346-365

35. Warnecke A, MellottA, Roemer A, LenarzT, Staecker $H$ (2017) Advances in translational inner ear stem cell research. Hear Res 353:76-86

36. Roemer A, Koehl U, Majdani O, Kloess S, Falk C, Haumann S, Lenarz T, Kral A, Warnecke A (2016) Biohybrid cochlear implants in human neurosensory restoration. Stemcell Res Ther 7:148

37. https://clinicaltrials.gov/ct2/show/study/ NCT02132130 